Check for updates

Cite this: RSC Adv., 2018, 8, 22216

Received 7th May 2018

Accepted 8th June 2018

DOI: $10.1039 / \mathrm{c} 8 \mathrm{ra} 03898 \mathrm{~h}$

rsc.li/rsc-advances

\section{Dual-modal imaging and excellent anticancer efficiency of cisplatin and doxorubicin loaded $\mathrm{NaGdF}_{4}: \mathrm{Yb}^{3+} / \mathrm{Er}^{3+}$ nanoparticles $\uparrow$}

\author{
Zhiyang Zhang, Jiayi Sheng, (D) Miaomiao Zhang, Xiaoyan Ma, Zhirong Geng (iD) * \\ and Zhilin Wang (1D) *
}

$\mathrm{NaGdF}_{4}: \mathrm{Yb}^{3+} / \mathrm{Er}^{3+}$ nanoparticles were synthesized via a modified hydrothermal route. The dependence of structure and morphology on the dosage of sodium polyacrylate was studied by X-ray diffraction (XRD) and transmission electron microscopy (TEM). The as-prepared nanoparticles could be used for $T_{2}$ weighted magnetic resonance imaging due to the paramagnetism of $\mathrm{Gd}^{3+}$. cis-dichlorodiamineplatinum (CDDP) could be loaded onto $\mathrm{NaGdF}_{4}: \mathrm{Yb}^{3+} / \mathrm{Er}^{3+}$ nanoparticles through binding carboxyl in the form of $\mathrm{Pt}-\mathrm{O}$ bonds, and doxorubicin (DOX) could be loaded via hydrogen bonding. DOX could also be loaded onto the $\mathrm{NaGdF}_{4}-\mathrm{CDDP}$ composite in the same manner, and the loading efficiency of both drugs remained unchanged. Three as-prepared drug delivery systems were used for tumor inhibition both in vitro and in vivo, and the results indicated that $\mathrm{NaGdF}_{4}-\mathrm{CDDP}-\mathrm{DOX}$ displayed the greatest inhibitory capacity.

\section{Introduction}

Anti-tumor drugs can be toxic to normal tissues and organs when killing tumor cells. ${ }^{1,2}$ However, drug delivery system based on drug-loaded nanoparticles can enter tumors due to their enhanced permeability and retention effects, ${ }^{3,4}$ release drugs, and inhibit tumor growth while reducing side effects to normal tissues and organs caused by the nonspecific accumulation of drugs.5.,6 Many types of nanoparticles with excellent biocompatibility have been chosen to establish such drug delivery systems, such as $\mathrm{Au}^{7}{ }^{7} \mathrm{SiO}_{2},{ }^{8,9}$ polymers, ${ }^{4,6,10}$ carbon nanomaterials, ${ }^{11}$ magnetic nanoparticles, ${ }^{12,13}$ rare-earth fluoride nanoparticles, ${ }^{14,15}$ and others. Because rare-earth nanoparticles exhibit superb luminescence properties originating from the $\mathrm{f}-\mathrm{f}$ electronic transition in the $4 \mathrm{f}$ electrons of rare-earth ions, these nanoparticles can be used to trace nanoparticles loaded with drugs. Therefore, rare-earth nanoparticles rank among the most common nanoparticles used to establish drug-delivery systems. ${ }^{16}$ Due to their weak auto-fluorescence background, minimum photodamage to organs and depth of lightpenetration in tissues when infrared radiation is used as the emission light, ${ }^{17-19}$ rare-earth doped upconversion nanoparticles are especially suitable for tracing and drug delivery. ${ }^{20}$

State Key Laboratory of Coordination Chemistry, Collaborative In-novation Center of Advanced Microstructure, School of Chemistry and Chemical Engineering, Nanjing University, Nanjing 210023, P. R. China. E-mail: gengzr@nju.edu.cn; wangzl@nju. edu.cn; Fax: +86-25-89687761; Tel: +86-25-89689026

$\dagger$ Electronic supplementary information (ESI) available. See DOI: 10.1039/c8ra03898h
As a familiar matrix, $\mathrm{NaGdF}_{4}$ nanoparticles doped with various rare-earth ions can emit various upconversion luminescence spectra. ${ }^{17,21,22}$ In addition to a superb upconversion luminescence property, the paramagnetism of $\mathrm{Gd}^{3+}$ ions makes rare-earth doped $\mathrm{NaGdF}_{4}$ nanoparticles suitable for both upconversion luminescence imaging and magnetic resonance imaging. ${ }^{23,24}$ Chemotherapy drugs, ${ }^{25}$ photodynamics therapy drugs ${ }^{26}$ gene segments, ${ }^{27}$ and other molecules, can be loaded onto rare-earth doped $\mathrm{NaGdF}_{4}$ nanoparticles to build drug delivery systems, which have been confirmed to be useful for tumor inhibition. Chemotherapy is the most common clinical cancer treatment, and usually, two or more chemotherapy drugs are used simultaneously during treatment. Although $\mathrm{NaGdF}_{4}$ nanoparticles loaded with two drugs for cancer treatment have been reported, ${ }^{28}$ the preparation process was complicated, and the loading efficiency could be influenced during the loading process by the hydrophobic interactions of both drugs. Thus, using a simple method to prepare nanoparticles for loading two drugs simultaneously is essential.

Herein, a revised solvothermal method in which sodium polyacrylate (PAAs), acting as a chelating agent, was used to synthesize $\mathrm{NaGdF}_{4}: \mathrm{Yb}^{3+} / \mathrm{Er}^{3+}$ nanoparticles. ${ }^{29}$ Carboxyl groups of PAAs on the surface rendered these as-prepared $\mathrm{NaGdF}_{4}$ :$\mathrm{Yb}^{3+} / \mathrm{Er}^{3+}$ nanoparticles hydrophilic and thus suitable for biological application. Green upconversion luminescence, which was used to monitor the cellular uptake process of the drugloaded nanoparticles could be observed upon excitation with a $980 \mathrm{~nm}$ CW laser. $\mathrm{NaGdF}_{4}: \mathrm{Yb}^{3+} / \mathrm{Er}^{3+}$ nanoparticles could also be used as a magnetic resonance imaging agent, due to the paramagnetism of $\mathrm{Gd}^{3+}$ ions. 
cis-Dichlorodiamineplatinum (CDDP) loaded $\mathrm{NaGdF}_{4}: \mathrm{Yb}^{3+} /$ $\mathrm{Er}^{3+}$ nanoparticles $\left(\mathrm{NaGdF}_{4}-\mathrm{CDDP}\right)$ were prepared through the binding of CDDP to carboxyl groups at the surface of the nanoparticles by Pt-O bonds. Doxorubicin (DOX) could bind to $\mathrm{NaGdF}_{4}: \mathrm{Yb}^{3+} / \mathrm{Er}^{3+}$ nanoparticles and the $\mathrm{NaGdF}_{4}-\mathrm{CDDP}$ compound via hydrogen bond interactions with the carboxyl groups to prepare DOX loaded $\mathrm{NaGdF}_{4}: \mathrm{Yb}^{3+} / \mathrm{Er}^{3+}$ nanoparticles $\left(\mathrm{NaGdF}_{4}-\mathrm{DOX}\right)$ and DOX loaded $\mathrm{NaGdF}_{4}-\mathrm{CDDP}$ compounds ( $\left.\mathrm{NaGdF}_{4}-\mathrm{CDDP}-\mathrm{DOX}\right)$ (Scheme 1). The as-loaded drugs could be released in both physiological and subacid conditions, and they were released more rapidly under sub-acid conditions, which were similar to the tumor microenvironment. These asprepared drug delivery systems were demonstrated to be effective for tumor inhibition both in vitro and in vivo, and the twodrug-loaded $\mathrm{NaGdF}_{4}-\mathrm{CDDP}-\mathrm{DOX}$ compounds exhibited a more pronounced therapeutic effect.

\section{Materials and methods}

\section{Materials}

$\mathrm{Gd}\left(\mathrm{NO}_{3}\right)_{3} \cdot 6 \mathrm{H}_{2} \mathrm{O}, \mathrm{Yb}\left(\mathrm{NO}_{3}\right)_{3} \cdot 6 \mathrm{H}_{2} \mathrm{O}$, and $\operatorname{Er}\left(\mathrm{NO}_{3}\right)_{3} \cdot 6 \mathrm{H}_{2} \mathrm{O}$ were purchased from Shanghai Diyang Chemical Co., Ltd. Sodium polyacrylate (PAAs) was purchased from Sigma-Aldrich Co., Ltd. CDDP was obtained from Shandong Boyuan Chemical Co., Ltd. DOX was purchased from Adamas Co., Ltd. Ethylene glycol (EG) was obtained from Nanjing Chemical Reagent Co., Ltd. Other chemical reagents were purchased from Sinopharm Chemical Reagent Co., Ltd. All reagents were used as received without further purification.

\section{Preparation of $\mathrm{NaGdF}_{4}: \mathrm{Yb}^{3+} / \mathrm{Er}^{3+}$ nanoparticles}

$\mathrm{NaGdF}_{4}: \mathrm{Yb}^{3+} / \mathrm{Er}^{3+}$ nanoparticles were prepared through a modified solvothermal route. A total of $1.2 \mathrm{mmol}$ of $\mathrm{Ln}\left(\mathrm{NO}_{3}\right)_{3} \cdot 6 \mathrm{H}_{2} \mathrm{O}(\mathrm{Ln}=\mathrm{Gd}, \mathrm{Yb}, \mathrm{Er}, \mathrm{Gd}: \mathrm{Yb}: \mathrm{Er}=78: 20: 2)$ and $2.4 \mathrm{mmol}$ of $\mathrm{NaCl}$ were dissolved in $20 \mathrm{~mL}$ of EG. Then, a certain amount of PA PAAs As was added to the solution. After stirring for $1 \mathrm{~h}, 10 \mathrm{~mL}$ of EG containing $5 \mathrm{mmol} \mathrm{NH}_{4} \mathrm{~F}$ was added to the mixture under stirring. The mixture was then transferred into a $50 \mathrm{~mL}$ Teflon-lined stainless steel autoclave and heated at $200{ }^{\circ} \mathrm{C}$ for $12 \mathrm{~h}$. After the autoclave was cooled to room

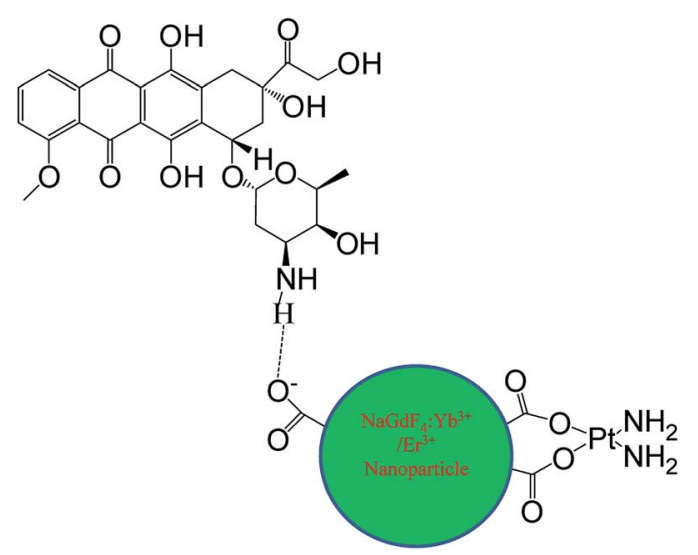

Scheme 1 The supposed chemical structure of the synthesized material $\mathrm{NaGdF}_{4}-\mathrm{CDDP}-\mathrm{DOX}$. temperature, the white powders were collected by centrifugation, washed with ethanol three times and kept in ethanol.

\section{CDDP loading to $\mathrm{NaGdF}_{4}: \mathrm{Yb}^{3+} / \mathrm{Er}^{3+}$ nanoparticles}

A $\mathrm{NaGdF}_{4}-\mathrm{CDDP}$ composite was obtained by the following procedure: $25 \mathrm{mg}$ of $\mathrm{NaGdF}_{4}: \mathrm{Yb}^{3+} / \mathrm{Er}^{3+}$ nanoparticles was dispersed in $10 \mathrm{~mL}$ of phosphate buffered saline (PBS buffer) $(\mathrm{pH}=6.0)$. After $5 \mathrm{~min}$ of ultrasonic pulsation, $7.5 \mathrm{mg}$ of CDDP was added to the above mixture, which was then stirred in the dark for $12 \mathrm{~h}$. The as-prepared $\mathrm{NaGdF}_{4}-\mathrm{CDDP}$ composite was centrifuged and washed with distilled water several times to remove the residual CDDP. All of the supernatants were collected, and the CDDP concentration in the supernatant was detected by inductively coupled plasma mass spectrometry. The drug loading content was calculated by subtraction.

\section{DOX loading to $\mathrm{NaGdF}_{4}: \mathrm{Yb}^{3+} / \mathrm{Er}^{3+}$ nanoparticles and $\mathrm{NaGdF}_{4}-$ CDDP composite}

A total of $2 \mathrm{mg}$ of $\mathrm{NaGdF}_{4}: \mathrm{Yb}^{3+} / \mathrm{Er}^{3+}$ nanoparticles and $2 \mathrm{mg}$ of $\mathrm{NaGdF}_{4}-\mathrm{CDDP}$ composite $\left(\mathrm{NaGdF}_{4}: \mathrm{Yb}^{3+} / \mathrm{Er}^{3+}\right.$ equivalent) were each dispersed in $1 \mathrm{~mL}$ of PBS buffer $(\mathrm{pH}=8.0)$. After $5 \mathrm{~min}$ of ultrasonic pulsation, $200 \mu \mathrm{L}$ of DOX $(2 \mathrm{mM})$ was added to each mixture, and the mixtures were shaken in the dark at the speed of $200 \mathrm{rpm}$ overnight. $\mathrm{NaGdF}_{4}-\mathrm{DOX}$ and $\mathrm{NaGdF}_{4}-\mathrm{CDDP}-\mathrm{DOX}$ were collected by centrifugation. The concentrations of DOX in the supernatants were measured using ultraviolet and visible spectrophotometry, and the DOX loading contents were assessed by subtraction.

\section{In vitro release of CDDP and DOX from $\mathrm{NaGdF}_{4}-\mathrm{CDDP}-\mathrm{DOX}$ composite}

The releases of CDDP and DOX from the $\mathrm{NaGdF}_{4}-\mathrm{CDDP}-\mathrm{DOX}$ composite were evaluated using $\mathrm{PBS}$ buffer with various $\mathrm{pH}$ values (7.4 and 5.5). Typically, $1 \mathrm{mg}$ of $\mathrm{NaGdF}_{4}-\mathrm{CDDP}-\mathrm{DOX}$ composite was dispersed in $1 \mathrm{~mL}$ of PBS buffer, and the mixture containing Eppendorf tubes were shaken in the dark at $37^{\circ} \mathrm{C}$ for various time periods. After $5 \mathrm{~min}$ centrifugation, the supernatants were collected. The amounts of released CDDP and DOX were detected using inductively coupled plasma mass spectrometry and ultraviolet and visible spectrophotometry, respectively.

\section{Cellular uptake of $\mathrm{NaGdF}_{4}-\mathrm{CDDP}, \mathrm{NaGdF}_{4}-\mathrm{DOX}$ and $\mathrm{NaGdF}_{4}-$ CDDP-DOX}

The cellular uptake of the $\mathrm{NaGdF}_{4}-\mathrm{CDDP}$ composite was monitored by detecting the upconversion luminescence of the $\mathrm{NaGdF}_{4}: \mathrm{Yb}^{3+} / \mathrm{Er}^{3+}$ nanoparticles. Briefly, HeLa cells were planted on coverslips in a 6-well plate at a density of $2.0 \times 10^{5}$ cells per well overnight for attachment. After being rinsed with PBS buffer, the cells were incubated in culture medium containing $\mathrm{NaGdF}_{4}-$ $\operatorname{CDDP}\left(500 \mu \mathrm{g} \mathrm{mL}{ }^{-1}\right)$ for $24 \mathrm{~h}$ at $37{ }^{\circ} \mathrm{C}$ in $5 \% \mathrm{CO}_{2}$. Then, the coverslip were washed with PBS three times to remove residual nanoparticles, and the cells were fixed using a $4 \%$ paraformaldehyde solution for $10 \mathrm{~min}$. After being washed with PBS buffer, the side of the coverslip that contained cells was turned 
onto a glass slide containing glycerol. The upconversion luminescence imaging was performed using an optical microscope, with a CW NIR laser at $\lambda_{\mathrm{ex}}=980 \mathrm{~nm}$ as an additional excitation source. The cellular uptake process of $\mathrm{NaGdF}_{4}-\mathrm{DOX}$ and $\mathrm{NaGdF}_{4}-\mathrm{CDDP}-\mathrm{DOX}$ was assessed using laser confocal fluorescence microscopy to detect the luminescence of DOX. A total of $1.0 \times 10^{5} \mathrm{HeLa}$ cells were planted in a $35 \mathrm{~mm}$ Petri dish at $37^{\circ} \mathrm{C}$ in $5 \% \mathrm{CO}_{2}$ overnight until attachment. Then the cells were washed with PBS buffer twice, and incubated with $\mathrm{NaGdF}_{4}-\mathrm{DOX}$

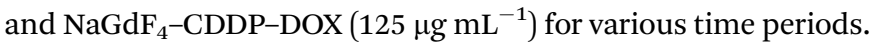
After the excess nanoparticles were washed off with PBS, the cells were observed using a laser confocal fluorescence microscope at the excitation wavelength of $488 \mathrm{~nm}$.

\section{In vitro cytotoxicity assay}

The cytotoxicity of sodium polyacrylate, polyacrylate and acrylate, CDDP, DOX, $\mathrm{NaGdF}_{4}: \mathrm{Yb}^{3+} / \mathrm{Er}^{3+}$ nanoparticles, $\mathrm{NaGdF}_{4}-\mathrm{CDDP}$, $\mathrm{NaGdF}_{4}-\mathrm{DOX}$ and $\mathrm{NaGdF}_{4}-\mathrm{CDDP}-\mathrm{DOX}$ was measured using the 3-(4,5-dimethylthiazol-2-yl)-2,5-diphenyltetrazolium bromide (MTT) assay against HeLa cells. HeLa cells were seeded in 96-well plates at a density of $2.0 \times 10^{4}$ cells per well in culture medium at $37{ }^{\circ} \mathrm{C}$ in $5 \% \mathrm{CO}_{2}$ overnight until attachment. Then, fresh medium containing various quantities of determinants was added to the wells, and the cells were subsequently incubated for 24 or $48 \mathrm{~h}$. Next, $20 \mu \mathrm{L}$ of MTT ( $5 \mathrm{mg} \mathrm{mL}^{-1}$ ) was added to the wells, and the mixtures were incubated for another $4 \mathrm{~h}$. After the medium was extracted, $150 \mu \mathrm{L}$ of DMSO was added to resolve formazan. The absorbance of formazan was monitored at $570 \mathrm{~nm}$ using an automatic enzyme-linked immunosorbent assay plate reader, and the cytotoxicity was expressed as the percentage of cell viability based on the data of four replicate tests.

\section{In vivo tumor inhibition}

ICR mice were obtained from the Model Animal Research Centre of Nanjing University and maintained in animal facilities of Jiangsu Province Hospital of Chinese Medicine. The mice were allowed free access to rodent feed and tap water, under the Chinese Guidance of Humane Use of Laboratory Animals. The mice were sacrificed by cervical vertebra dislocation after anesthesia (pentobarbital sodium, $40 \mathrm{mg} \mathrm{kg}^{-1}$ ), and tumors were collected. The protocol was approved by the Committee on the Ethics of Animal Experiments of Jiangsu Province Hospital of Chinese Medicine (Permit number: 2017-DWLL-8). H22 tumor cells were dispersed in normal saline and inoculated subcutaneously into ICR mice at the armpit of the left forelimb at a density of $1.0 \times 10^{7}$ cells per mouse. On the fifth day after inoculation, when the tumor volume $\left(V=a \times b^{2} / 2\right.$, where $a$ and $b$ are the longest and shortest diameter of the tumor, respectively) reached 80 to $100 \mathrm{~mm}^{3}$, the mice were randomly allocated into 8 groups with 5 mice in each group. As bovine serum albumin (BSA) could contribute to the dispersion of drug loaded nanoparticles and is compatible with mice, all the determinants were dispersed in a $1.5 \%$ BSA solution. ${ }^{30,31}$ Tumor bearing mice were injected via the tail vein on the 1st and 7th day with BSA solution, $\mathrm{NaGdF}_{4}: \mathrm{Yb}^{3+} / \mathrm{Er}^{3+}$ nanoparticles, CDDP (1.1 mg kg-1), DOX $\left(0.75 \mathrm{mg} \mathrm{kg}{ }^{-1}\right), \operatorname{CDDP}\left(1.1 \mathrm{mg} \mathrm{kg}^{-1}\right)+\operatorname{DOX}\left(0.75 \mathrm{mg} \mathrm{kg}^{-1}\right)$,
$\mathrm{NaGdF}_{4}-\mathrm{CDDP}\left(1.1 \mathrm{mg} \mathrm{kg}{ }^{-1}\right.$ on $\mathrm{CDDP}$ basis), $\mathrm{NaGdF}_{4}-\mathrm{DOX}$ (0.75 $\mathrm{mg} \mathrm{kg}^{-1}$ on DOX basis) and $\mathrm{NaGdF}_{4}-\mathrm{CDDP}-\mathrm{DOX}(1.1 \mathrm{mg}$ $\mathrm{kg}^{-1}$ on CDDP basis, $0.75 \mathrm{mg} \mathrm{kg}^{-1}$ on DOX basis). For the tumor volume calculations, the two dimensions of the tumors were measured using Vernier caliper every other day for 13 days. After the mice were sacrificed on the 13th day, the tumors were peeled off and weighted to assess the tumor inhibition efficiency.

\section{Characterization}

$\mathrm{X}$-ray powder diffraction (XRD) of the as-prepared $\mathrm{NaGdF}_{4}: \mathrm{Yb}^{3+} /$ $\mathrm{Er}^{3+}$ nanoparticles was performed on a Bruker D8 Advanced instrument with $\mathrm{Cu} \mathrm{K} \alpha$ radiation $(\lambda=0.15406 \mathrm{~nm})$. The morphology of the products was assessed using JEM-1011 transmission electron microscopy (TEM) with an acceleration voltage of $100 \mathrm{kV}$. Ligand on the surface of the products was analyzed using a Bruker IR vector22 infrared spectrometer. Thermogravimetric analysis (TGA) was carried out on a PerKinElmer Pyris 1 thermo-analytical instrument. X-ray photoelectron spectroscopy (XPS) was performed using Thermo Scientific K-Alpha equipment. The concentration of Pt in the supernatant was detected by inductively coupled plasma mass spectrometry (ICP-MS) using a standard Plasma-Quad II instrument. Ultraviolet and visible spectrophotometry (UV) performed on a Bruker UV-3600 was used to measure the concentration of DOX in the supernatant. Upconversion luminescent spectra were acquired on a Zolix luminescence spectrometer equipped with a $980 \mathrm{~nm}$ laser device. Magnetic resonance imaging (MRI) was performed using a Burker PharmaScan 7.0T small animal MRI scanner. The cellular uptake of $\mathrm{NaGdF}_{4}-\mathrm{CDDP}$ was observed using a Zeiss primo star optical microscope equipped with $980 \mathrm{~nm}$ CW laser, and images were taken with a Samsung pad. The uptake process of $\mathrm{NaGdF}_{4}-\mathrm{DOX}$ and $\mathrm{NaGdF}_{4}-\mathrm{CDDP}-$ DOX was observed using a Zeiss LSM 710 confocal laser fluorescence microscope at the exaction wavelength of $488 \mathrm{~nm}$.

\section{Results and discussion}

The crystal structures of the as-obtained $\mathrm{NaGdF}_{4}: \mathrm{Yb}^{3+} / \mathrm{Er}^{3+}$ nanoparticles were influenced by the dosage of PAAs. As shown in Fig. 1a, when the dosage of PAAs was $100 \mathrm{mg}$, the products were primarily cubic phase $\mathrm{NaGdF}_{4}$ (JCPDS no. 27-0697) with

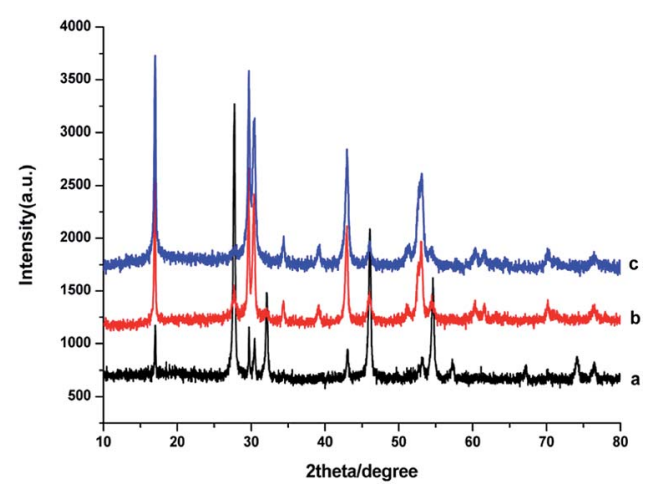

Fig. 1 XRD patterns of products prepared in the presence of various amount of PAAs (a) $100 \mathrm{mg}$, (b) $200 \mathrm{mg}$, (c) $300 \mathrm{mg}$. 
hexagonal phase $\mathrm{NaGdF}_{4}$ (JCPDS no. 27-0699) sparsely mixed in. The product was a mixture of cubic and hexagonal phase $\mathrm{NaGdF}_{4}$ (Fig. 1b) when the dosage of PAAs was $200 \mathrm{mg}$. When the dosage of PAAs was raised to $300 \mathrm{mg}$, the product was primarily hexagonal phase $\mathrm{NaGdF}_{4}$ (Fig. 1c). As reported previously, ${ }^{29,32}$ hexagonal phase $\mathrm{NaGdF}_{4}$ was more commonly achieved when the crystallization process was slow. Raising the dosage of PAAs decreased the effective concentration of $\mathrm{Gd}^{3+}$ cations, and further reduced the crystallization velocity of $\mathrm{NaGdF}_{4}$. Therefore, the proportion of hexagonal phase $\mathrm{NaGdF}_{4}$ increased when more $\mathrm{NaOH}$ was used.

The morphology of the as-prepared $\mathrm{NaGdF}_{4}: \mathrm{Yb}^{3+} / \mathrm{Er}^{3+}$ nanoparticles was observed using TEM. The $\mathrm{NaGdF}_{4}: \mathrm{Yb}^{3+} / \mathrm{Er}^{3+}$ nanoparticles were small particles with a diameter less than $20 \mathrm{~nm}$ when the dosage of PAAs was $100 \mathrm{mg}$ (Fig. 2a). Fig. 2b shows that when the amount of PAAs was increased to $200 \mathrm{mg}$, hexagonal prisms and nanospheres with an agglomerated structure were obtained. According to the XRD patterns, these prisms and nanospheres were hexagonal phase $\mathrm{NaGdF}_{4}: \mathrm{Yb}^{3+} /$ $\mathrm{Er}^{3+}$. When the dosage of PAAs was increased to $300 \mathrm{mg}$, the number of nanoparticles with a size of $20 \mathrm{~nm}$ decreased and the product were primarily nanospheres with a cluster structure (Fig. 2c).

IR spectra were used to identify the capping ligands on the surface of these $\mathrm{NaGdF}_{4}: \mathrm{Yb}^{3+/} \mathrm{Er}^{3+}$ nanoparticles (Fig. 3). The peaks at 2953 and $2880 \mathrm{~cm}^{-1}$ correspond to the asymmetric and symmetric stretching vibrations of the $\mathrm{C}-\mathrm{H}$ bond in PAAs. The peaks at 1575 and $1458 \mathrm{~cm}^{-1}$ represent the asymmetric and symmetric stretching vibrations of bound carboxyl groups respectively, suggesting the binding of carboxyl to rare earth ions on the surface of these $\mathrm{NaGdF}_{4}: \mathrm{Yb}^{3+} / \mathrm{Er}^{3+}$ nanoparticles. ${ }^{29,33}$ The strong peak at $1728 \mathrm{~cm}^{-1}$ is assigned to the $\mathrm{C}=\mathrm{O}$ asymmetric vibration of the free carboxyl groups of PAAs which improve the hydrophilicity of the as-obtained $\mathrm{NaGdF}_{4}: \mathrm{Yb}^{3+} / \mathrm{Er}^{3+}$ nanoparticles. ${ }^{29,34}$

Thermogravimetric analysis was used to assess the amount of capped ligands on the surface of the as-prepared $\mathrm{NaGdF}_{4}$ :$\mathrm{Yb}^{3+} / \mathrm{Er}^{3+}$ nanoparticles. Fig. 4 shows that all of the products lost

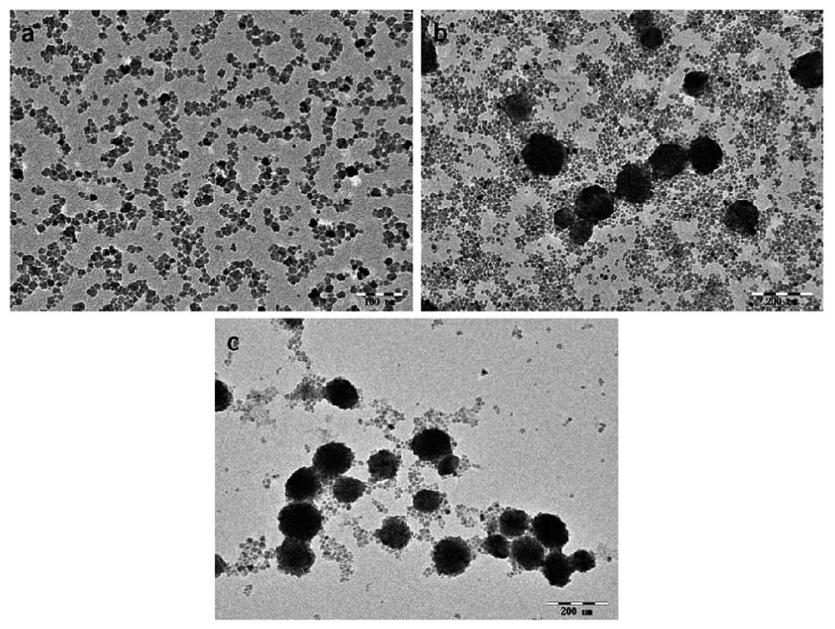

Fig. 2 TEM images of products prepared in the presence of various amount of PAAs (a) $100 \mathrm{mg}$, (b) $200 \mathrm{mg}$, (c) $300 \mathrm{mg}$. PAAs.

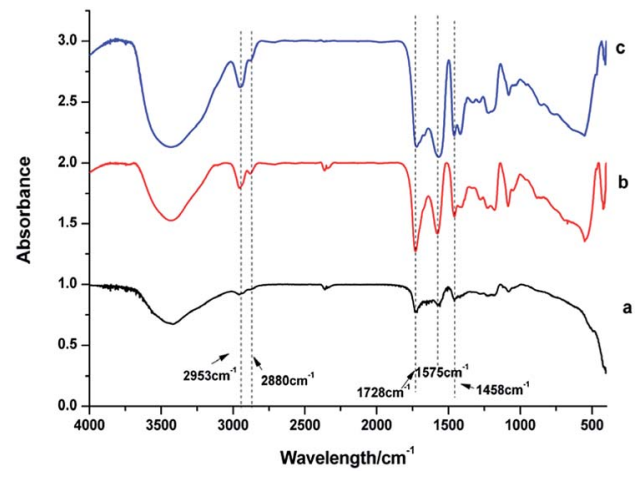

Fig. 3 IR spectra of products prepared in the presence of various amount of PAAs (a) $100 \mathrm{mg}$, (b) $200 \mathrm{mg}$, (c) $300 \mathrm{mg}$.

weight at the temperature of $371.1{ }^{\circ} \mathrm{C}$, indicating that the capped PAAs were oxidized. The degree of weight loss increased with increasing PAAs. However, the size of the particles was smaller and the specific surface area of the particles was larger when the dosage of PAAs was $200 \mathrm{mg}$, accordingly the particles could bind more PAAs. Thus, the weight loss of products obtained under the condition of $200 \mathrm{mg}$ PAAs (Fig. 4b) was higher than that of nanoparticles obtained under the condition of $300 \mathrm{mg}$ of PAAs (Fig. 4c).

Upconversion luminescence spectra were measured at room temperature (Fig. 5). When excited using a $980 \mathrm{~nm}$ CW laser, theses as-prepared $\mathrm{NaGdF}_{4}: \mathrm{Yb}^{3+} / \mathrm{Er}^{3+}$ nanoparticles emitted green lights. Emission peaks at $\sim 520, \sim 538$ and $\sim 652 \mathrm{~nm}$ correspond to the ${ }^{2} \mathrm{H}_{11 / 2} \rightarrow{ }^{4} \mathrm{I}_{15 / 2},{ }^{4} \mathrm{~S}_{3 / 2} \rightarrow{ }^{4} \mathrm{I}_{15 / 2}$ and ${ }^{4} \mathrm{~F}_{9 / 2} \rightarrow{ }^{4} \mathrm{I}_{15 /}$ ${ }_{2}$ transition in $\mathrm{Er}^{3+}$, respectively. ${ }^{35}$ At the same concentration, the luminescence intensity of products prepared with differing amount of PAAs was variable. It has been reported that rareearth doped hexagonal phase $\mathrm{NaGdF}_{4}$ exhibits a preferable luminescence property. ${ }^{36,37}$ In this study, the luminescence intensity decreased as the content of hexagonal phase $\mathrm{NaGdF}_{4}: \mathrm{Yb}^{3+} / \mathrm{Er}^{3+}$ nanoparticles increased, primarily because the agglomerated structure of these hexagonal phase $\mathrm{NaGdF}_{4}$ :$\mathrm{Yb}^{3+} / \mathrm{Er}^{3+}$ nanoparticles could lead to larger surface defect, which results in luminescence quenching. ${ }^{38}$

More amount of free carboxyl groups on the surface of the particles enable nanoparticles to bind more molecules, such as anticancer drugs, and stronger luminescence intensity

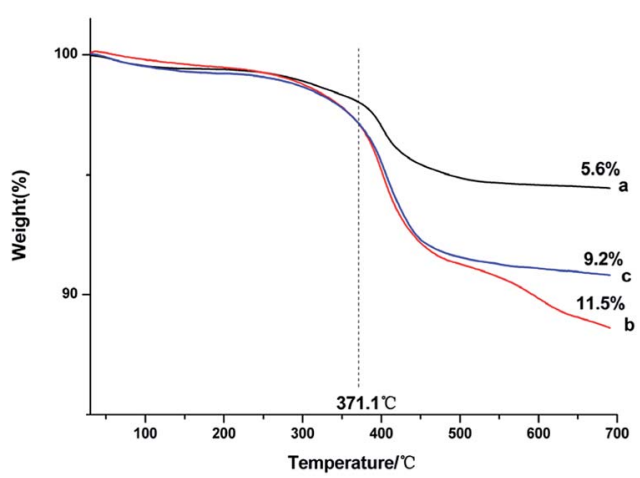

Fig. 4 TGA curves of products prepared in the presence of various amount of PAAs (a) $100 \mathrm{mg}$, (b) $200 \mathrm{mg}$, (c) $300 \mathrm{mg}$. 


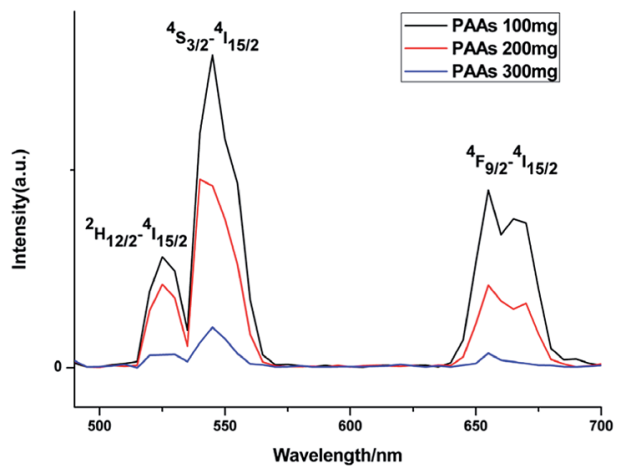

Fig. 5 Upconversion luminescence spectra of products prepared in the presence of various amount of PAAs.

enhances the cell imaging of drug-loaded nanoparticles. Thus, $\mathrm{NaGdF}_{4}: \mathrm{Yb}^{3+} / \mathrm{Er}^{3+}$ nanoparticles synthesized with $200 \mathrm{mg}$ PAAs were chosen to establish the drug delivery system.

XPS was used to study the loading process of CDDP in $\mathrm{NaGdF}_{4}: \mathrm{Yb}^{3+} / \mathrm{Er}^{3+}$ nanoparticles. As shown in Fig. 6, the binding energy of Gd 4d, Er 4d, Yb 4d, F 1s and Na 1s in $\mathrm{NaGdF}_{4}: \mathrm{Yb}^{3+} / \mathrm{Er}^{3+}$ was located at 142.9, 172.8, 187.4, 685.1, and $1072.2 \mathrm{eV}$ respectively. The photoelectron peaks at 284.9 and $532.3 \mathrm{eV}$ correspond to the $\mathrm{C} 1 \mathrm{~s}$ and $\mathrm{O} 1 \mathrm{~s}$ respectively. The peak at $74 \mathrm{eV}$ is assigned to $\mathrm{Pt}$ $4 \mathrm{f}$, indicating the binding of CDDP. The close-up view of the Pt $4 \mathrm{f}$ region (inset of Fig. 6) exhibited two peaks at 71.8 and $75.6 \mathrm{eV}$, which are peaks of $\mathrm{Pt} 4 \mathrm{f} 7 / 2$ and Pt 4f5/2, viz., the binding energy of $\mathrm{Pt}$ II in Pt-O-C(O)-NaGdF $4: \mathrm{Yb}^{3+} / \mathrm{Er}^{3+}$ nanoparticles. ${ }^{39,40}$ Therefore, CDDP loaded to $\mathrm{NaGdF}_{4}: \mathrm{Yb}^{3+} / \mathrm{Er}^{3+}$ nanoparticles through a Pt-O bond. The content of residual CDDP in the supernatant was detected using ICP-MS, and the loading capacity was calculated using the subtraction method. The mass percentage of CDDP in $\mathrm{NaGdF}_{4}$-CDDP composite was determined to be $c a .12 .9 \%$.

Fig. 7 shows the UV spectra of DOX in the supernatant before and after DOX loading onto $\mathrm{NaGdF}_{4}: \mathrm{Yb}^{3+} / \mathrm{Er}^{3+}$ nanoparticles and $\mathrm{NaGdF}_{4}-\mathrm{CDDP}$ respectively. In $\mathrm{ddH}_{2} \mathrm{O}$ (Fig. $7 \mathrm{~b}$ and d), when keeping the amount the same $\left(\mathrm{NaGdF}_{4}: \mathrm{Yb}^{3+} / \mathrm{Er}^{3+}\right.$ equivalent), the $\mathrm{NaGdF}_{4}: \mathrm{Yb}^{3+} / \mathrm{Er}^{3+}$ nanoparticles loaded more DOX compared with the $\mathrm{NaGdF}_{4}$-CDDP composite. However, the loading capacity was almost equal in PBS buffer $(\mathrm{pH}=8.0)$. Moreover, the loading amounts of both nanoparticles in PBS buffer $(\mathrm{pH}=8.0)$ were much larger than those in $\mathrm{ddH}_{2} \mathrm{O}$. Fig. 8

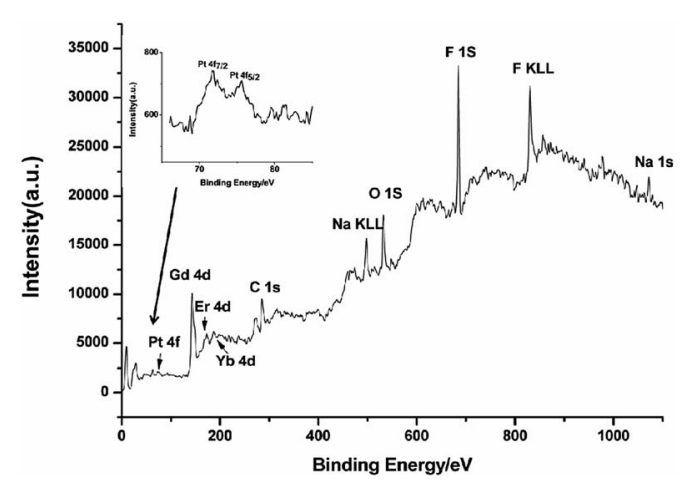

Fig. 6 XPS spectrum of $\mathrm{NaGdF}_{4}-\mathrm{CDDP}$. Inset: enlarged spectrum of Pt4f.

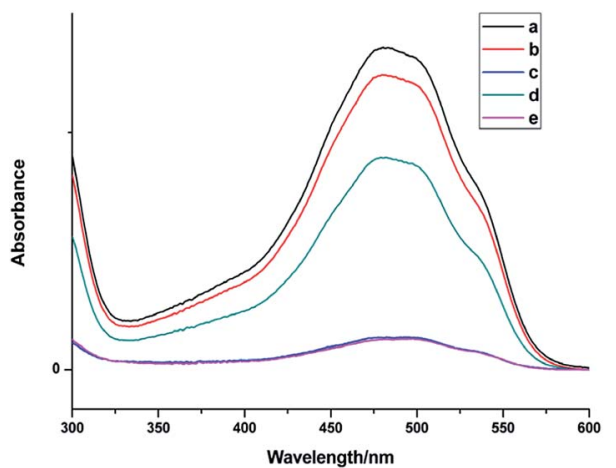

Fig. 7 UV-Vis absorbance spectra of DOX in the supernatant before and after loading onto $\mathrm{NaGdF}_{4}: \mathrm{Yb}^{3+} / \mathrm{Er}^{3+}$ nanoparticles (a) before loading, (b) after loading onto $\mathrm{NaGdF}_{4}-\mathrm{CDDP}$ in $\mathrm{ddH}_{2} \mathrm{O}$, (c) after loading onto $\mathrm{NaGdF}_{4}-\mathrm{CDDP}$ in PBS buffer $(\mathrm{pH}=8.0)$, (d) after loading onto $\mathrm{NaGdF}_{4}: \mathrm{Yb}^{3+} / \mathrm{Er}^{3+}$ in $\mathrm{ddH}_{2} \mathrm{O}$, (e) after loading onto $\mathrm{NaGdF}_{4}: \mathrm{Yb}^{3+} /$ $\mathrm{Er}^{3+}$ in PBS buffer ( $\left.\mathrm{pH}=8.0\right)$.

shows the loading amounts of $\mathrm{NaGdF}_{4}: \mathrm{Yb}^{3+} / \mathrm{Er}^{3+}$ nanoparticles and the $\mathrm{NaGdF}_{4}-\mathrm{CDDP}$ composite with various concentrations of DOX in PBS buffer $(\mathrm{pH}=8.0)$, illustrating that the loading capacity of DOX is almost equal, and therefore, the loading of CDDP has no influence on the carrying of DOX.

In $\mathrm{ddH}_{2} \mathrm{O},-\mathrm{NH}_{2}$ in DOX. $\mathrm{HCl}$ was protonated, and could bind $-\mathrm{COO}^{-}$in PAAs via electrostatic interactions. ${ }^{41}$ However, due to the weak electrolyte property of PAAs, $-\mathrm{COO}^{-}$would hydrolyze into $-\mathrm{COOH}$, which could weaken the electrostatic interaction between $-\mathrm{NH}_{3}{ }^{+}$and $-\mathrm{COO}^{-}$. In addition, because CDDP was bound in the form of $\mathrm{Pt}-\mathrm{O}$ bond, occupying $-\mathrm{COO}^{-}$ in PAAs would also decrease the loading amount of DOX. In PBS buffer ( $\mathrm{pH}=8.0),-\mathrm{NH}_{3}{ }^{+}$in DOX. $\mathrm{HCl}$ lost $\mathrm{H}^{+}$and bound to $-\mathrm{COO}^{-}$in PAAs through hydrogen-bond interaction. Moreover, the ionization of $-\mathrm{COO}^{-}$contributed to the swelling of PAAs, which exposed more $-\mathrm{COO}^{-}{ }^{42}$ resulting in an increased DOX loading amount. The subtraction method was used to calculate the DOX loading capacity and the mass percentages of DOX in the $\mathrm{NaGdF}_{4}-\mathrm{DOX}$ composite and the $\mathrm{NaGdF}_{4}-\mathrm{CDDP}-\mathrm{DOX}$ composite were $8.9 \%$ and $7.8 \%$, respectively. ICP-MS was introduced to detect CDDP in the supernatant after the $\mathrm{NaGdF}_{4}-\mathrm{CDDP}$ was loaded with DOX, and only $1.5 \%$ of the loaded CDDP could be detected, indicating that the loading of DOX scarcely influenced the loading amount of CDDP.

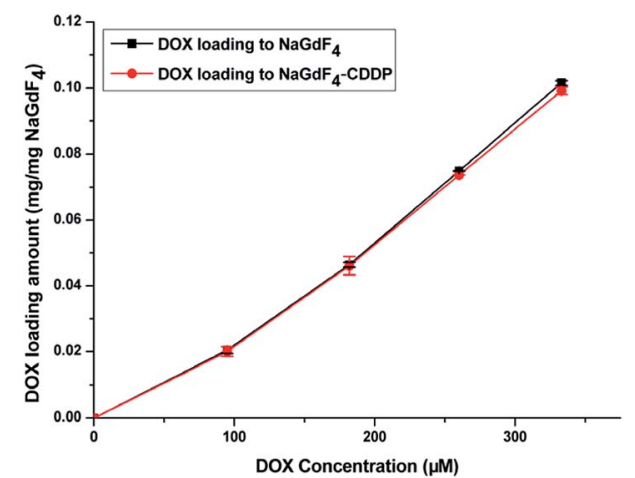

Fig. 8 Loading amount of DOX onto $\mathrm{NaGdF}_{4}: \mathrm{Yb}^{3+} / \mathrm{Er}^{3+}$ and $\mathrm{NaGdF}_{4}-$ CDDP versus concentration of DOX. 
An acidic environment resembles the microenvironment of tumor cells, ${ }^{43}$ and the $\mathrm{pH}$ value of the physiological environment is approximately 7.3 to 7.4. Accordingly, PBS buffer with a $\mathrm{pH}$ value of 5.5 and 7.4 was used to simulate the environment of tumor cells and normal physiology, respectively. Fig. 9 shows the CDDP and DOX release from the $\mathrm{NaGdF}_{4}-\mathrm{CDDP}-\mathrm{DOX}$ composite (mass concentration of DOX is $7.8 \%$ ) in PBS buffer with $\mathrm{pH}=5.5$ and $\mathrm{pH}$ $=7.4$. Similar to a previous study, ${ }^{44}$ the release of CDDP from the $\mathrm{NaGdF}_{4}-\mathrm{CDDP}-\mathrm{DOX}$ composite in PBS buffer with a $\mathrm{pH}$ of 5.5 was much faster compared with PBS buffer with a $\mathrm{pH}$ of 7.4, indicating that the acidic environment enhanced the release of CDDP. Similarly, for DOX, the release rate was higher in PBS with a $\mathrm{pH}$ of 5.5 than in PBS with a $\mathrm{pH}$ of 7.4. In the case of $\mathrm{pH} 5.5, \mathrm{H}^{+}$in PBS buffer could disrupt hydrogen-bond interactions between $-\mathrm{NH}_{2}$ in DOX and $-\mathrm{COO}^{-}$in PAAs, inducing the quick release of DOX. The hydrogen-bond interaction was partly weakened when the $\mathrm{pH}$ value of PBS buffer was 7.4, so a small amount of DOX could release at first. However, decreasing the $\mathrm{pH}$ value would enhance the protonation of $-\mathrm{NH}_{2}$, which could strengthen the static electricity with $-\mathrm{COO}^{-}$, inducing further binding of DOX as the time extended. In short, an acidic environment enhances the release of anti-cancer drugs, making the $\mathrm{NaGdF}_{4}-\mathrm{CDDP}-\mathrm{DOX}$ composite suitable for drug delivery.

HeLa cells were used to monitor the cellular uptake process of the $\mathrm{NaGdF}_{4}-\mathrm{CDDP}$ composite by detecting the upconversion luminescence of $\mathrm{NaGdF}_{4}: \mathrm{Yb}^{3+} / \mathrm{Er}^{3+}$. HeLa cells incubated with the composite were examined with a microscope equipped with a $980 \mathrm{~nm} \mathrm{CW}$ laser. After incubation with the $\mathrm{NaGdF}_{4}-\mathrm{CDDP}$ composite for $24 \mathrm{~h}$, compared with the bright field image
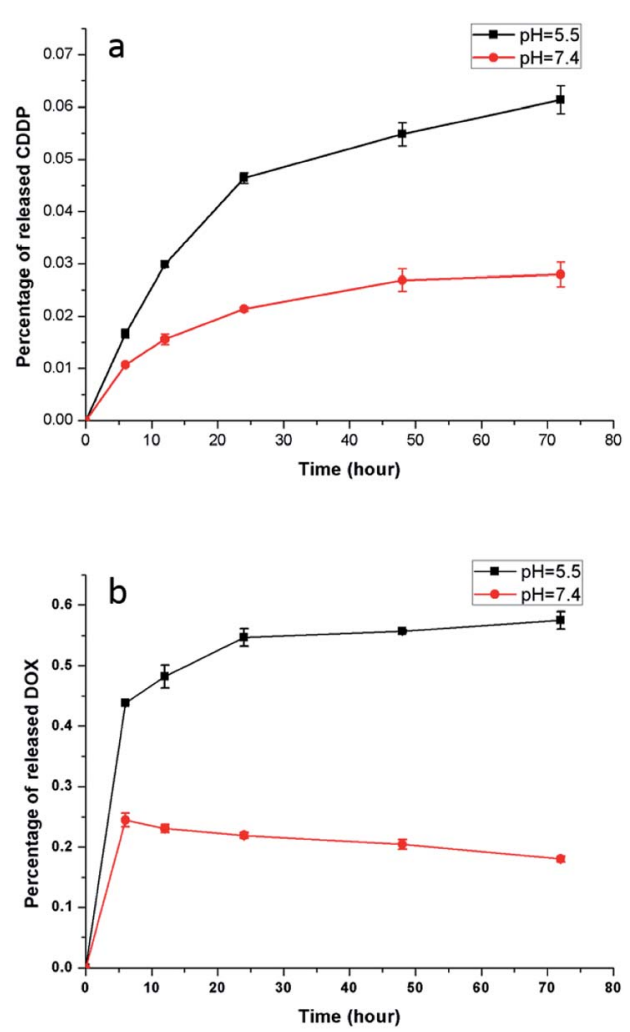

Fig. 9 Drug release profile from $\mathrm{NaGdF}_{4}-\mathrm{CDDP}-\mathrm{DOX}$ over time at various $\mathrm{pH}$ value (a) CDDP, (b) DOX.

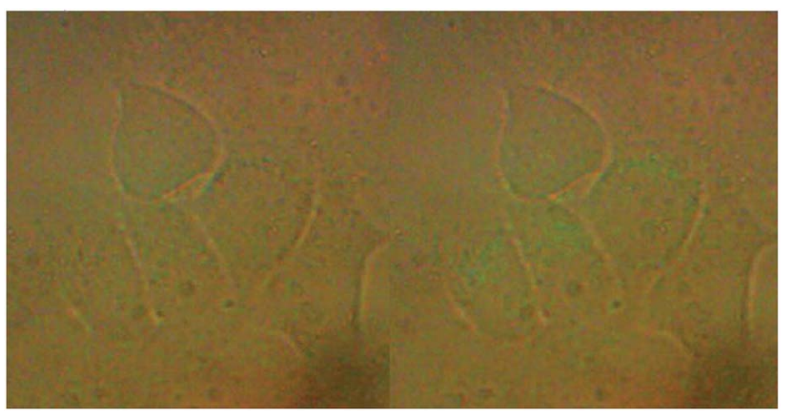

Fig. 10 Upconversion luminescence images of HeLa cells stained with $\mathrm{NaGdF}_{4}-\mathrm{CDDP}$ composite at $37^{\circ} \mathrm{C}$. Bright field image in the left and upconversion luminescence image on the right.

(Fig. 10a), cells in the upconversion luminescence image (Fig. 10b) exhibited green luminescence, revealing that the $\mathrm{NaGdF}_{4}-\mathrm{CDDP}$ composite could be internalized by HeLa cells.

Upon excitation at $488 \mathrm{~nm}$, DOX emitted intense red luminescence. Accordingly, the cellular uptake processes of DOX loaded $\mathrm{NaGdF}_{4}: \mathrm{Yb}^{3+} / \mathrm{Er}^{3+}$ nanoparticles and the $\mathrm{NaGdF}_{4}-\mathrm{CDDP}$ composite could be monitored via observing the luminescence of DOX. ${ }^{45}$ Fig. 11 and 12 show the laser confocal fluorescence microscope images of HeLa cells incubated with $\mathrm{NaGdF}_{4}-\mathrm{DOX}$ and the $\mathrm{NaGdF}_{4}-\mathrm{CDDP}-\mathrm{DOX}$ composite for various durations. The confocal laser scanning microscope (CLSM) images on the left shows that after incubation for $1 \mathrm{~h}$, red light could be observed in HeLa cells, indicating the uptake of $\mathrm{NaGdF}_{4}-\mathrm{DOX}$ and the $\mathrm{NaGdF}_{4}-\mathrm{CDDP}-\mathrm{DOX}$ composite. When the incubation time was prolonged to $2 \mathrm{~h}$, the luminescence intensity enhanced, which indicating that more of the drug loaded nanoparticles entered the cells. Merged images combining the laser confocal fluorescence microscope images and bright field
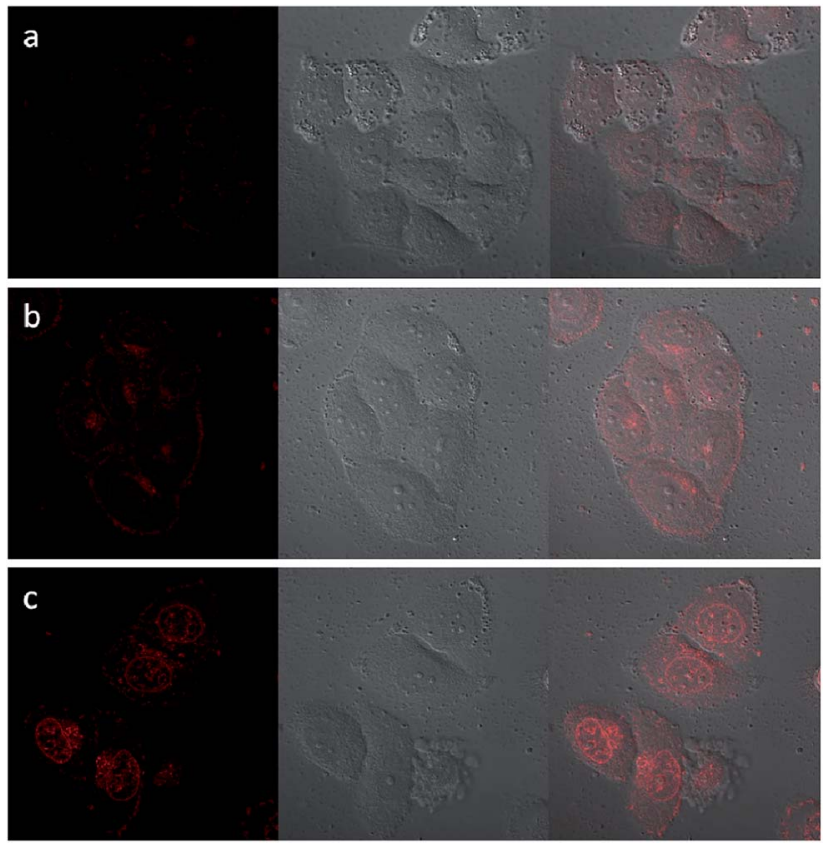

Fig. 11 CLFM images of HeLa cells stained with $\mathrm{NaGdF}_{4}-\mathrm{DOX}$ for (a) $1 \mathrm{~h}$, (b) $2 \mathrm{~h}$, (c) $6 \mathrm{~h}$ on the left, bright field images in the middle, and merged images on the right. 

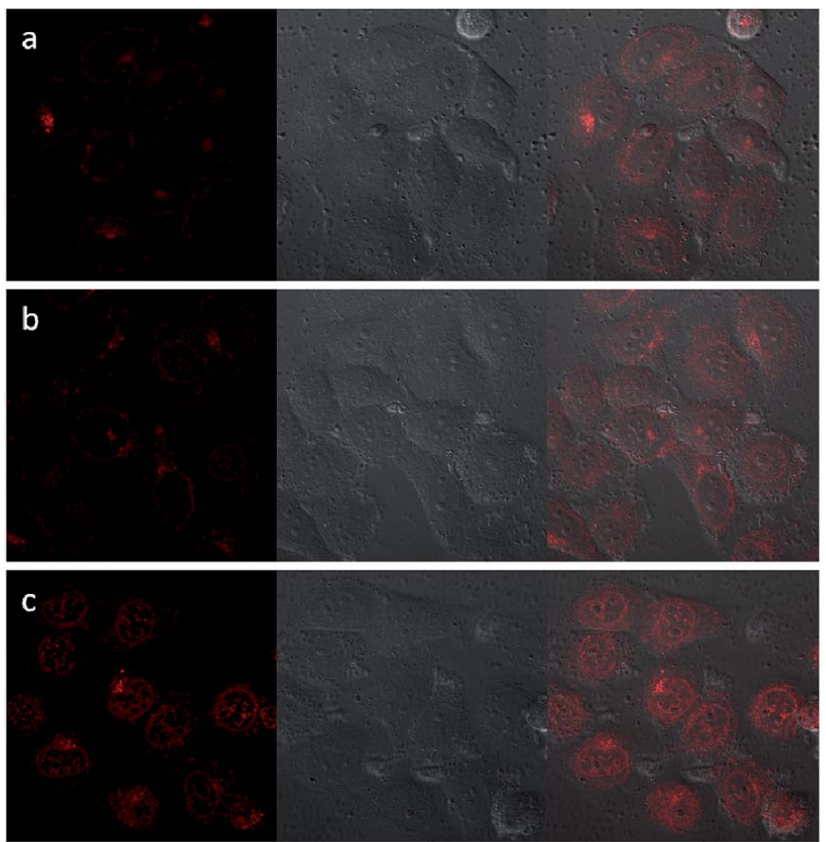

Fig. 12 CLFM images of HeLa cells stained with $\mathrm{NaGdF}_{4}-\mathrm{CDDP}-\mathrm{DOX}$ for (a) $1 \mathrm{~h}$, (b) $2 \mathrm{~h}$, (c) $6 \mathrm{~h}$ on the left, bright field images in the middle, and merged images on the right.

images revealed that red light was primarily observed in the cytoplasm. When the incubation time was increased to $6 \mathrm{~h}$, intense red light could be detected both the cytoplasm and the cell nucleus, revealing that DOX released from drug loaded nanoparticles and entered cell nucleus. Therefore, $\mathrm{NaGdF}_{4}{ }^{-}$ DOX and the $\mathrm{NaGdF}_{4}-\mathrm{CDDP}-\mathrm{DOX}$ composite could be internalized into cells in a time-dependent manner.

MTT assays were used to estimate the cytotoxicity of CDDP, DOX and a combination of CDDP and DOX. As shown in Fig. 13a, the half-maximal inhibitory concentration $\left(\mathrm{IC}_{50}\right)$ of CDDP against HeLa cells was $7.30 \mu \mathrm{M}$ and $2.46 \mu \mathrm{M}$ after $24 \mathrm{~h}$ and $48 \mathrm{~h}$ of incubation respectively, and the $\mathrm{IC}_{50}$ value of DOX against HeLa cells was $0.42 \mu \mathrm{M}$ and $0.09 \mu \mathrm{M}$ (Fig. 13b) when the incubation time was $24 \mathrm{~h}$ and $48 \mathrm{~h}$ respectively. When the mass percentage of DOX in the $\mathrm{NaGdF}_{4}-\mathrm{CDDP}-\mathrm{DOX}$ composite was $7.8 \%$, the molar ratio of loaded CDDP and DOX was 2.86:1. This was the ratio chosen to assess the antitumor capacity of a combination of CDDP and DOX. When CDDP and DOX were used simultaneously, the $\mathrm{IC}_{50}$ values were $0.27 \mu \mathrm{M}$ and $0.05 \mu \mathrm{M}$ (DOX equivalent, Fig. 13c), which were less than the $\mathrm{IC}_{50}$ value for each component alone, indicating that CDDP also had an inhibiting effect.

$$
\mathrm{CI}=\frac{D_{1}}{D_{\mathrm{m} 1}}+\frac{D_{2}}{D_{\mathrm{m} 2}}
$$

The Combination Index (CI) and equivalent diagram analysis method were used to study the mechanism of action when these two drugs were used simultaneously. ${ }^{46}$ The CI can be calculated using formula (1), in which $D_{1}$ and $D_{2}$ are the dosages of drug 1 and drug 2 in combination when producing some specified effect (such as half-maximal inhibitory), and $D_{\mathrm{m} 1}$ and $D_{\mathrm{m} 2}$ are
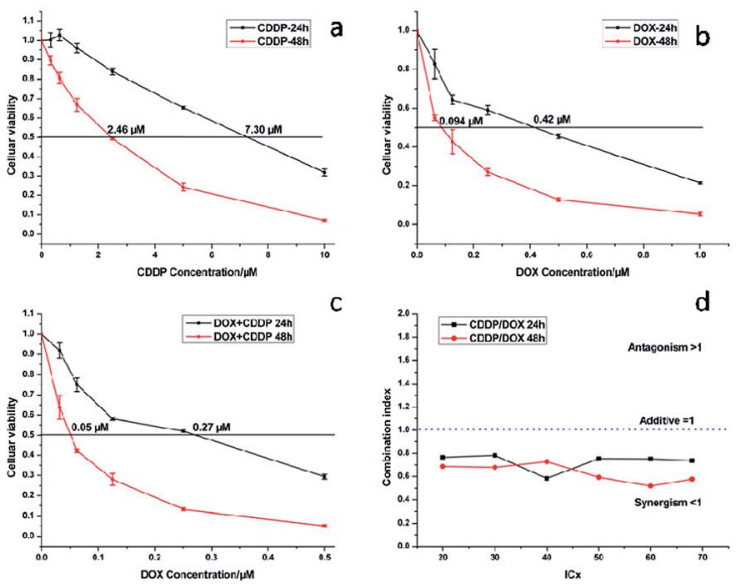

Fig. 13 Cytotoxicity of CDDP (a), DOX (b) and CDDP/DOX combination (c) against HeLa cancer cell lines at 24 and $48 \mathrm{~h}$, combination index (Cl) curves (d) of CDDP/DOX combinations.

the dosages that have the same antitumor effect of the drugs when they are used alone. CI values higher than, equal to and lower than 1 reveal antagonism, additivity and synergism, respectively. As shown in Fig. 13d, the CI values under different $\mathrm{IC}_{X}$ conditions are lower than 1 , indicating the synergism of CDDP and DOX when they are combined. Therefore, combining CDDP and DOX effectively enhances their antitumor capacity.

$\mathrm{NaGdF}_{4}: \mathrm{Yb}^{3+} / \mathrm{Er}^{3+}$ nanoparticles exhibited high biocompatibility. ${ }^{47,48}$ As shown in Fig. $\mathrm{S} 1, \uparrow$ sodium polyacrylate, polyacrylate and acrylate are almost no toxic towards Hela cells. More than $75 \%$ of the cells survived even after incubation with a high concentration of $\mathrm{NaGdF}_{4}: \mathrm{Yb}^{3+} / \mathrm{Er}^{3+}$ nanoparticles (2000 $\mu \mathrm{g} \mathrm{mL}^{-1}$ ) for $48 \mathrm{~h}$ (Fig. 14), suggesting the feasibility of these nanoparticles for drug delivery. $\mathrm{NaGdF}_{4}-\mathrm{CDDP}$ and $\mathrm{NaGdF}_{4}{ }^{-}$ DOX exhibited obvious cytotoxicity when compared with $\mathrm{NaGdF}_{4}: \mathrm{Yb}^{3+} / \mathrm{Er}^{3+}$ nanoparticles, revealing the establishment of a drug delivery system. The $\mathrm{IC}_{50}$ value of $\mathrm{NaGdF}_{4}-\mathrm{CDDP}$ against HeLa cells was $131 \mu \mathrm{M}$ and $27 \mu \mathrm{M}$ after $24 \mathrm{~h}$ and $48 \mathrm{~h}$ of incubation, respectively (Fig. 15a), and that of the $\mathrm{NaGdF}_{4}-\mathrm{DOX}$ composite against HeLa cells was $1.18 \mu \mathrm{M}$ and $0.31 \mu \mathrm{M}$ after $24 \mathrm{~h}$ and $48 \mathrm{~h}$ of incubation, respectively (Fig. 15b). The $\mathrm{IC}_{50}$ values of the as- obtained composites were larger than those of

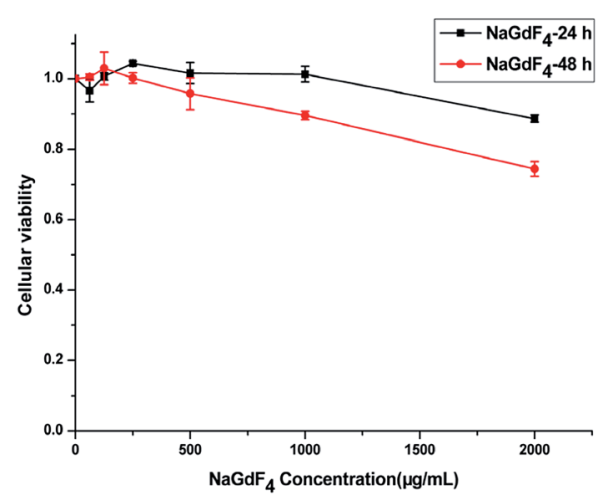

Fig. 14 Cytotoxicity of $\mathrm{NaGdF}_{4}: \mathrm{Yb}^{3+} / \mathrm{Er}^{3+}$ nanoparticles against HeLa cancer cell lines at 24 and $48 \mathrm{~h}$. 

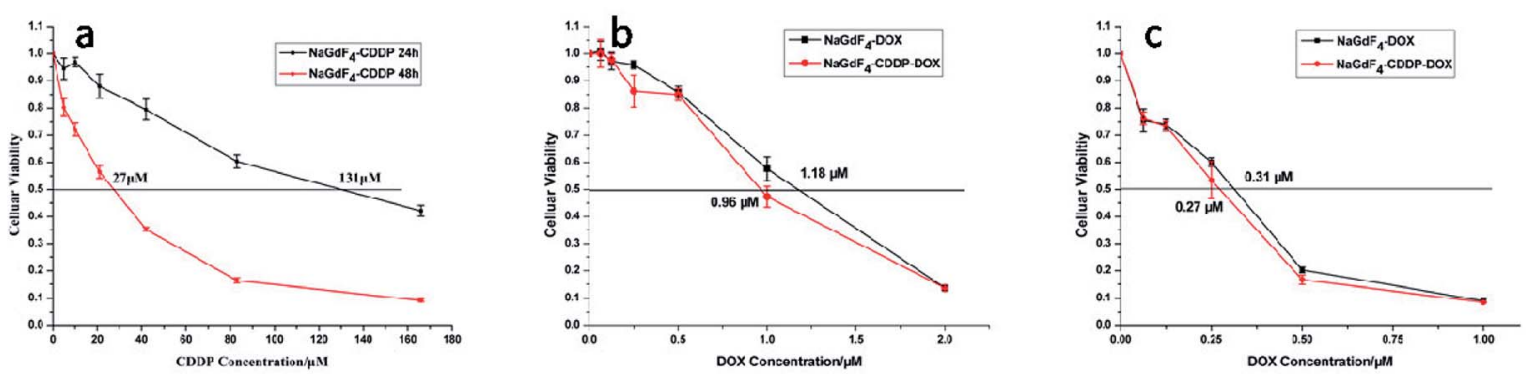

Fig. 15 Cytotoxicity of $\mathrm{NaGdF}_{4}-\mathrm{CDDP}$ (a), cytotoxicity of $\mathrm{NaGdF}_{4}-\mathrm{DOX}$ and $\mathrm{NaGdF}_{4}-\mathrm{CDDP}-\mathrm{DOX}$ at 24 (b) and $48 \mathrm{~h}$ (c), respectively.

CDDP and DOX alone, likely because the composites required time to enter the cells, and they released drugs slowly due to the favorable releasing profile in the acidic environment of cancer cells. In addition, the cytotoxicity of $\mathrm{NaGdF}_{4}-\mathrm{CDDP}$ was much less than that of CDDP, primarily because CDDP released very slowly due to the strength of the Pt-O bond. Because the cytotoxicity of $\mathrm{NaGdF}_{4}-\mathrm{DOX}$ was more pronounced than that of $\mathrm{NaGdF}_{4}-\mathrm{CDDP}$, the $\mathrm{NaGdF}_{4}-\mathrm{CDDP}-\mathrm{DOX}$ composite carrying less DOX $(50 \mu \mathrm{L}$ of DOX $\cdot \mathrm{HCl}$ solution was used in preparation of $\mathrm{NaGdF}_{4}-\mathrm{CDDP}-\mathrm{DOX}$, and the mass percentage of DOX in $\mathrm{NaGdF}_{4}-\mathrm{CDDP}-\mathrm{DOX}$ composite was approximately $1.7 \%$ ) was chosen to study the antitumor capacity of the two-drug-loaded composite against HeLa cells. As shown in Fig. $15 \mathrm{c}$, the $\mathrm{IC}_{50}$ value of the $\mathrm{NaGdF}_{4}-\mathrm{CDDP}-\mathrm{DOX}$ composite was $0.96 \mu \mathrm{M}$ and $0.27 \mu \mathrm{M}$ (DOX equivalent) after $24 \mathrm{~h}$ and $48 \mathrm{~h}$ of incubation, respectively, which were less than that of the nanoparticles loading DOX only. Compared with $\mathrm{NaGdF}_{4}-\mathrm{CDDP}$ and $\mathrm{NaGdF}_{4}{ }^{-}$ DOX, the $\mathrm{NaGdF}_{4}-\mathrm{CDDP}-\mathrm{DOX}$ composite exhibited a stronger anticancer effect, indicating the successful construction of a two-drug-loaded delivery system.

$\mathrm{NaGdF}_{4}: \mathrm{Yb}^{3+} / \mathrm{Er}^{3+}$ nanoparticles could be used as carriers for drug delivery in vivo because they are highly biocompatible. All of the drugs were injected via the tail vein on the first and seventh day, and the tumor volumes from different groups varied as time went on, as shown in Fig. 16. The CDDP, DOX and CDDP + DOX groups showed superb antitumor capacities, and the combination of CDDP and DOX exhibited the best antitumor effect. Similar to unloaded drugs, the group that received $\mathrm{NaGdF}_{4}-\mathrm{CDDP}-\mathrm{DOX}$ presented a better inhibitory effect when compared with $\mathrm{NaGdF}_{4}-\mathrm{CDDP}$ and $\mathrm{NaGdF}_{4}-\mathrm{DOX}$.

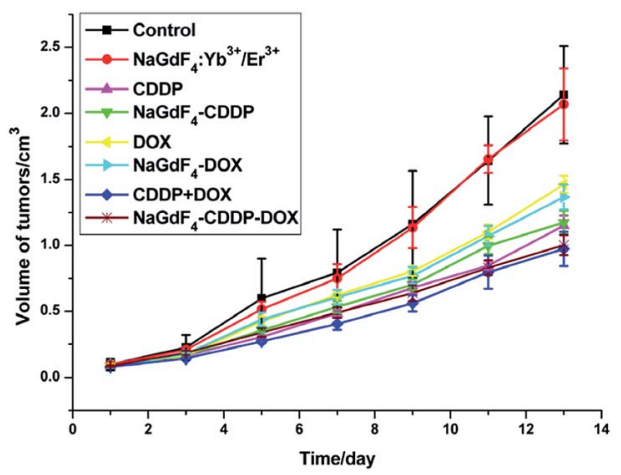

Fig. 16 Volume of tumors achieved from $\mathrm{H} 22$ tumor-bearing mice after indicated treatment.
The tumor weights directly reflected the inhibitory effect of the various treatments. After the tumors were peeled off and weighed on the last day (Fig. 17), consistent with the tumor volumes, CDDP + DOX and $\mathrm{NaGdF}_{4}-\mathrm{CDDP}-\mathrm{DOX}$ showed the strongest antitumor effect. In addition, drug-loaded nanoparticles showed a similar inhibitory capacity similar to the corresponding drugs, revealing the effectiveness of drug delivery systems.

$$
1 / T=1 / T^{\circ}+r \times[\mathrm{Gd}]
$$

The magnetic resonance relaxivity of the $\mathrm{NaGdF}_{4}: \mathrm{Yb}^{3+} / \mathrm{Er}^{3+}$ nanoparticles (obtained with $200 \mathrm{mg}$ PAAs) was measured on a 7.0 T small animal MRI scanner. The relaxivity value of $r$ can be calculated using formula (2), in which $T$ and [Gd] are relaxation time and concentration of Gd, respectively. Fig. 18 shows the relaxivity curves of the $\mathrm{NaGdF}_{4}: \mathrm{Yb}^{3+} / \mathrm{Er}^{3+}$ nanoparticles, and the relaxivity values of $r_{1}$ and $r_{2}$ were $0.95 \mathrm{mM}^{-1} \mathrm{~S}^{-1}$ and 113.04 $\mathrm{mM}^{-1} \mathrm{~S}^{-1}$, respectively. The ratio of the transversal $\left(r_{2}\right)$ to longitudinal $\left(r_{1}\right)$ magnetic resonance relaxivity was 119 , which ranked these $\mathrm{NaGdF}_{4}: \mathrm{Yb}^{3+} / \mathrm{Er}^{3+}$ nanoparticles among the highperformance $T_{2}$ contrast agents. ${ }^{25,49}$

Fig. 19 shows the $T_{2}$ weighted MR images of as-prepared $\mathrm{NaGdF}_{4}: \mathrm{Yb}^{3+} / \mathrm{Er}^{3+}$ nanoparticles at various concentrations, and the brightness of the image decreased as the concentration of $\mathrm{Gd}^{3+}$ increased, indicating that the as-prepared nanoparticles were suitable $T_{2}$ contrast agents.

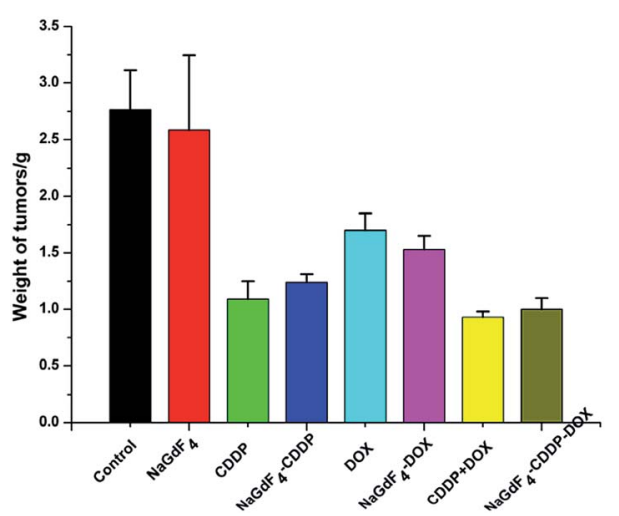

Fig. 17 Tumor weights of each indicated group at the last day of experiment. 


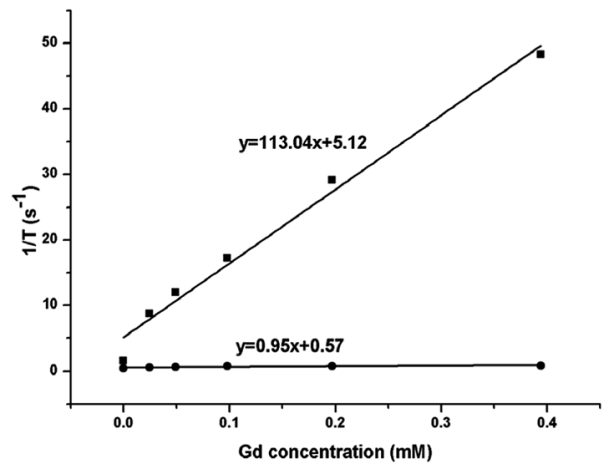

Fig. 18 The $r_{1}\left(\mathbf{)}\right.$ ) and $r_{2}(\mathbf{\square})$ relaxivity curves of $\mathrm{NaGdF}^{4}: \mathrm{Yb}^{3+} / \mathrm{Er}^{3+}$ nanoparticles at room temperature.

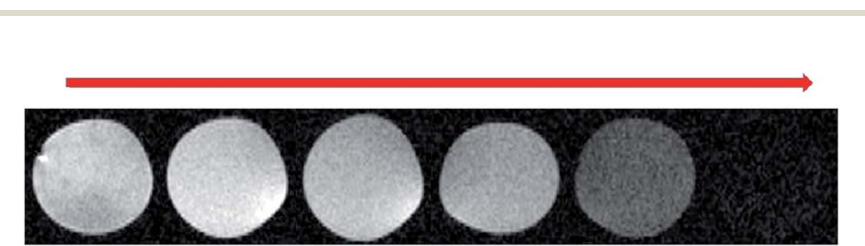

Fig. $19 T_{2}$-weighted $\mathrm{MRI}$ contrast images of $\mathrm{NaGdF}_{4}: \mathrm{Yb}^{3+} / \mathrm{Er}^{3+}$ nanoparticles with various $\mathrm{Gd}$-concentrations from zero to $0.394 \mathrm{mM}$ collected using a 7.0 T animal MRI scanner.

\section{Conclusion}

$\mathrm{NaGdF}_{4}: \mathrm{Yb}^{3+} / \mathrm{Er}^{3+}$ nanoparticles coated with carboxyl groups were prepared using a one-step solvothermal method, and the structure, morphology and luminescence influenced by the dosage of PAAs was also studied. CDDP and DOX could be loaded onto $\mathrm{NaGdF}_{4}: \mathrm{Yb}^{3+} / \mathrm{Er}^{3+}$ nanoparticles through $\mathrm{Pt}-\mathrm{O}$ bonding and hydrogen bonding, respectively. DOX could also be loaded onto $\mathrm{NaGdF}_{4}-\mathrm{CDDP}$ via hydrogen bonding, and the loading capacity of CDDP and DOX was not influenced by each other. Anticancer assays in vitro and in vivo indicated that CDDP and DOX loaded nanoparticles exhibited a higher antitumor capacity when compared with single-drug-loaded nanoparticles. In addition, the paramagnetism of $\mathrm{Gd}^{3+}$ made the $\mathrm{NaGdF}_{4}: \mathrm{Yb}^{3+}$ / $\mathrm{Er}^{3+}$ nanoparticles suitable as $T_{2}$ weighted MRI agents.

\section{Conflicts of interest}

There are no conflicts to declare.

\section{Acknowledgements}

This work is supported by the National Natural Science Foundation of China (21527809, 21475059 and 21775069).

\section{Notes and references}

1 D. Böhme and A. G. Beck-Sikinger, J. Pept. Sci., 2015, 21, 186200.

2 K. Strebhardt and A. Ullrich, Nat. Rev. Cancer, 2008, 8, 473480.

3 D. Peer, J. M. Karp, S. Hong, O. C. Farokhzad, R. Margalit and R. Langer, Nat. Nanotechnol., 2007, 2, 751-760.
$4 \mathrm{X}$. Zhen, X. Wang, C. Xie, W. Wu and X. Q. Jiang, Biomaterials, 2013, 34, 1372-1382.

5 H. Maeda, Adv. Enzyme Regul., 2001, 41, 189-207.

6 Y. R. Xiong, W. W. Jiang, Y. Shen, H. Y. Li, C. M. Sun, A. Ouahab and J. S. Tu, Biomaterials, 2012, 33, 7182-7293.

7 V. Shanmugam, Y. H. Chien, Y. S. Cheng, T. Y. Liu, C. C. Huang, C. H. Su, Y. S. Chen, U. Kumar, H. F. Hsu and C. S. Yeh, ACS Appl. Mater. Interfaces, 2014, 6, 4382-4393.

8 J. L. Gu, S. S. Su, Y. S. Li, Q. J. He, J. Y. Zhong and J. L. Shi, J. Phys. Chem. Lett., 2010, 1, 3446-3450.

9 C. Y. Lai, B. G. Trewyn, D. M. Jeftinija, K. Jeftinija, S. Xu, S. Jeftinija and V. S. Y. Lin, J. Am. Chem. Soc., 2003, 125, 4451-4459.

10 R. Haag and F. Kratz, Angew. Chem., Int. Ed., 2006, 45, 11981215.

11 M. Raoof, B. T. Cisneros, A. Guven, S. Phounsavath, S. J. Corr, L. J. Wilson and S. A. Curley, Biomaterials, 2013, 34, 1862-1869.

12 J. Z. Wang, X. Y. Wang, Y. J. Song, C. C. Zhu, J. Wang, K. Wang and Z. J. Guo, Chem. Commun., 2013, 49, 2786-2788.

13 D. F. Liu, W. Wu, X. Chen, S. Wen, X. Z. Zhang, Q. Ding, G. J. Teng and N. Gu, Nanoscale, 2012, 4, 2306-2310.

14 Y. Wu, D. M. Yang, X. J. Kang, P. A. Ma, S. S. Huang, Y. Zhang, C. X. Li and J. Lin, Dalton Trans., 2013, 42, 98529861.

15 R. C. Lv, S. L. Gai, Y. L. Dai, N. Niu, F. He and P. P. Yang, ACS Appl. Mater. Interfaces, 2013, 5, 10806-10818.

16 D. M. Yang, P. A. Ma, Z. Y. Hou, Z. Y. Cheng, C. X. Li and J. Lin, Chem. Soc. Rev., 2015, 44, 1416-1448.

17 G. Chen, T. Y. Ohulchanskyy, S. Liu, W. C. Law, F. Wu, M. T. Swihart, H. Ågren and P. N. Prasad, ACS Nano, 2012, 6, 2969-2977.

18 M. Haase and H. Schäfer, Angew. Chem., Int. Ed., 2011, 50, 5808.

19 H. H. Gorris, R. Ali, S. M. Saleh and O. S. Wolfbeis, Adv. Mater., 2011, 23, 1652.

20 G. Y. Chen, H. L. Qiu, P. N. Prasad and X. Y. Chen, Chem. Rev., 2014, 114, 5161-5214.

21 Q. Zhao, B. Q. Shao, W. Lu, W. Z. Lv, M. M. Jiao, L. F. Zhao and H. P. You, Dalton Trans., 2015, 44, 3745-3752.

22 F. He, N. Niu, L. Wang, J. Xu, Y. Wang, G. X. Yang, S. L. Gai and P. P. Yang, Dalton Trans., 2013, 42, 10019-10028.

23 F. Evanics, P. R. Diamente, F. C. J. M. van Veggel, G. J. Stanisz and R. S. Prosser, Chem. Mater., 2006, 18, 2499-2505.

24 J. Zhou, Y. Sun, X. X. Du, L. Q. Xiong, H. Hu and F. Y. Li, Biomaterials, 2010, 31, 3287-3295.

25 J. N. Liu, W. B. Bu, L. M. Pan, S. J. Zhang, F. Chen, L. P. Zhou, K. L. Zhao, W. J. Peng and J. L. Shi, Biomaterials, 2012, 33, 7282-7290.

26 Y. Park, H. M. Kim, J. H. Kim, K. C. Moon, B. Yoo, K. T. Lee, N. Lee, Y. Choi, W. Park, D. Ling, K. Na, W. K. Moon, S. H. Choi, H. S. Park, S. Y. Yoon, Y. D. Suh, S. H. Lee and T. Hyeon, Adv. Mater., 2012, 24, 5755-5761.

27 X. Wang, K. Liu, G. B. Yang, L. Cheng, L. He, Y. M. Liu, Y. G. Li, L. Guo and Z. Liu, Nanoscale, 2014, 6, 9198-9205.

28 G. Tian, W. Y. Yin, J. J. Jin, X. Zhang, G. M. Xing, S. J. Li, Z. J. Gu and Y. L. Zhao, J. Mater. Chem. B, 2014, 2, 1379-1389. 
29 Z. Wang, C. H. Liu, L. J. Chang and Z. P. Li, J. Mater. Chem., 2012, 22, 12186-12192.

30 D. Elgrabli, S. Abella-Gallart, O. Aguerre-Chariol, F. Robidel, F. Rogerieux, J. Boczkowski and G. Lacroix, Nanotoxicology, 2012, 1, 266-278.

31 X. Wang, T. Xia, M. C. Duch, Z. X. Ji, H. Y. Zhang, R. B. Li, B. B. Sun, S. J. Lin, H. Meng, Y. P. Liao, M. Y. Wang, T. B. Song, Y. Yang, M. C. Hersam and A. E. Nel, Nano Lett., 2012, 12, 3050-3061.

32 Y. Wei, F. Q. Lu, X. R. Zhang and D. P. Chen, Chem. Mater., 2006, 18, 5733-5737.

33 L. Y. Wang, Y. Zhang and Y. Y. Zhu, Nano Res., 2010, 3, 317325.

34 X. J. Wu, Q. B. Zhang, X. Wang, H. Yang and Y. M. Zhu, Eur. J. Inorg. Chem., 2011, 2158-2163.

35 G. S. Yi and G. M. Chow, Adv. Funct. Mater., 2006, 16, 23242329.

36 G. S. Yi and G. M. Chow, Chem. Mater., 2007, 19, 341-343.

37 F. Wang, Y. Han, C. S. Lim, Y. H. Lu, J. Wang, J. Xu, H. Y. Chen, C. Zhang, M. H. Hong and X. G. Liu, Nature, 2010, 463, 1061-1065.

38 H. X. Mai, Y. W. Zhang, L. D. Sun and C. H. Yan, J. Phys. Chem. C, 2007, 111, 13721-13729.

39 R. M. Xing, X. Y. Wang, C. L. Zhang, J. Z. Wang, Y. M. Zhang, Y. Song and Z. J. Guo, J. Mater. Chem., 2011, 21, 1114211149.
40 T. C. Deivaraj, W. X. Chen and J. Y. Lee, J. Mater. Chem., 2003, 13, 2555-2560.

41 M. Q. Li, Z. H. Tang, S. X. Lv, W. T. Song, H. Hong, X. B. Jing, Y. Y. Zhang and X. S. Chen, Biomaterials, 2014, 35, 38513864 .

42 S. C. Chen, Y. C. Wu, F. L. Mi, Y. H. Lin, L. C. Yu and H. W. Sung, J. Controlled Release, 2004, 96, 285-300.

43 I. F. Tannock and D. Rotin, Cancer Res., 1989, 49, 4373-4384.

44 J. Z. Wang, X. Y. Wang, Y. J. Song, J. Wang, C. L. Zhang, C. J. Chang, J. Yan, L. Qiu, M. M. Wu and Z. J. Guo, Chem. Sci., 2013, 4, 2605-2612.

45 Y. L. Dai, P. A. Ma, Z. Y. Cheng, X. J. Kang, X. Zhang, Z. Y. Hou, C. X. Li, D. M. Yang, X. F. Zhai and J. Lin, ACS Nano, 2012, 6, 3327-3338.

46 L. Zhao, M. G. Wientjes and J. L. S. An, Clin. Cancer Res., 2004, 10, 7994-8004.

47 H. Y. Xing, S. J. Zhang, W. B. Bu, X. P. Zheng, L. J. Wang, Q. F. Xiao, D. L. Ni, J. M. Zhang, L. P. Zhou, W. J. Peng, K. L. Zhao, Y. Q. Hua and J. L. Shi, Adv. Mater., 2014, 26, 3867-3872.

48 C. X. Li, D. M. Yang, P. A. Ma, Y. Y. Chen, Y. Wu, Z. Y. Hou, Y. L. Dai, J. H. Zhao, C. P. Sui and J. Lin, Small, 2013, 9, 41504159.

49 M. S. Martina, J. P. Fortin, C. Ménager, O. Clément, G. Barratt, C. Grabielle-Madelmont, F. Gazeau, V. Cabuil and S. Lesieur, J. Am. Chem. Soc., 2005, 127, 10676-10685. 